\title{
PROCESO CONSTRUCTIVO Y ORNAMENTAL DE LA CAPILLA DEL SANTÍSIMO SACRAMENTO DE LA PARROQUIA CORDOBESA DE SAN MIGUEL (1760-1762)
}

\section{CONSTRUCTIVE AND ORNAMENTAL PROCESS OF THE CHAPEL OF THE BLESSED SACRAMENT AT THE PARISH CHURCH OF SAN MIGUEL IN CORDOBA (1760-1762)}

\author{
Miguel Ángel Nieto MÁrquez \\ Proyecto de Investigación PGC2018-099323-B-I00: Arquitecturas del poder en el \\ Caribe y el Sudeste Asiático (1729-1764). España \\ ORCID: 0000-0002-8337-5072 \\ mamnm91@gmail.com
}

En este artículo se estudia el proceso constructivo y ornamental de la capilla del Sagrario de la parroquia de San Miguel de Córdoba. A partir de la consulta de las cuentas de la cofradía del Santísimo Sacramento de dicho templo y de otras fuentes, se ha podido documentar la autoría de la mayor parte de las obras de dicho espacio sacramental, algunas de ellas debidas a artistas de especial relevancia. De este modo, el presente texto viene a completar los estudios del fenómeno sacramental en la Córdoba del siglo XVIII.

Palabras clave: Eucaristía; Alonso Gómez de Sandoval; Pedro Ruiz Moreno; José Ruiz de Sarabia; Francisco Agustín.

This paper studies the constructive and ornamental process of the Chapel of the Blessed Sacrament at the Parish Church of San Miguel in Cordoba. It has been possible to document the authorship of most of the works of this sacramental space, some of them due to artists of special relevance, from the consultation of the accounts of the Brotherhood of the Blessed Sacrament of said temple and other sources. In this way, the present text complete the studies of the sacramental phenomenon in Cordoba in the $18^{\text {th }}$ century.

Keywords: Eucharist; Alonso Gómez de Sandoval; Pedro Ruiz Moreno; José Ruiz de Sarabia; Francisco Agustín. 
Aunque las hermandades sacramentales en Córdoba surgieron durante la primera mitad del siglo XVI, fue durante los obispados de fray Juan de Toledo y Pedro Fernández Manrique cuando aparecieron bajo el título del Santísimo Sacramento. Entre ellas se encontraba la de la parroquia de San Miguel, que según Nieto Cumplido lo haría entre los años 1537 y 1540². Los inventarios de estas cofradías recogen importante información acerca de sus bienes muebles, especialmente de los elementos que utilizaban en sus salidas procesionales y de las custodias donde se manifestaba el Santísimo ${ }^{2}$. Sin embargo, el elemento principal de estas cofradías fueron sus capillas, construidas y ornamentadas para mayor gloria del Santísimo Sacramento.

A través de los Paseos por Córdoba de Teodomiro Ramírez de Arellano, se conoce que la actual capilla sacramental de la parroquia de San Miguel no fue el primer espacio que tuvo su cofradía para el culto eucarístico. En el siglo XVII, la cofradía ocupaba otra a los pies de la nave del evangelio que se encontraba cerrada en la época de dicho autor, sirviendo de almacén. Según su testimonio, el interior estaba muy ornamentado, sobre todo la bóveda, aunque no se apreciaba bien por haberse levantado un entresuelo que la cubría. Sobre la puerta había una inscripción que revelaba la cronología de la obra: "Siendo hermano mayor Francisco de Támara, Familiar del Santo Oficio y Rector perpetuo Lic. Diego de Orozco año 1660"' Ciertamente, consultando las cuentas de la cofradía del período comprendido entre 1638 y 1773, siendo mayordomo de la misma Gabriel de Villarreal, aparece la noticia de la construcción de una capilla anterior, pero en 1656. Según se indica en el documento, con licencia del provisor y vicario general del obispado don Matías López de Valtablado, la hermandad solicitó ante el notario Alonso Pérez Moreno la compra de un lugar para erigir la capilla, que también serviría para enterramiento de sus hermanos cofrades. Con la escritura de venta tomada por el escribano Bartolomé Manuel Maldonado, el espacio fue adquirido el 18 de febrero por la cantidad de 600 reales, que fueron entregados a la fábrica de la parroquia y su obrero, el licenciado Diego de Góngora. Además, la corporación tuvo que desembolsar un total de 66 reales por la licencia del provisor, por los derechos de la escritura de venta y por la toma de posesión de la capilla ${ }^{4}$.

Según los gastos en materiales y en jornales que se reflejan en las cuentas, esta primera capilla debió ser de pequeñas dimensiones. Al respecto se ha podido descubrir que el maestro Juan López Pintor fue el encargado de realizar el hueco de la capilla por 450 reales, quedándose sin cobrar 50 por no haberla

1 Nieto Cumplido, 1991: 15-33.

2 Aranda Doncel, 2007: 284-285.

${ }^{3}$ Ramírez de Arellano, 2003: 8-9.

${ }^{4}$ Los datos que siguen, referentes a la capilla, están extraídos del mismo documento. Archivo General del Obispado de Córdoba (AGOC), sección Cofradías, Cuentas de la cofradía del Santísimo Sacramento de la parroquia de San Miguel, 1656. 
acabado. Se pagaron al cantero Pedro de la Toba 1.020 reales por los cimientos, 242 "de la Boca del hueco" y 1.600 "del frontal caydas del altar y pila de Agua bendita", concretándose también con el maestro mayor Juan Francisco Hidalgo la realización de la bóveda, cornisas y el acabado del hueco por 1.800 reales. Además, 154 reales serían para "raspar ladrillo y solar todas las delanteras de la Capilla", la cantidad de 86 reales para "solar La Capilla y sentar el frontal y Peana" y 392 serían entregados a los canteros Juan de Castilla y Andrés Gutiérrez por unas molduras de yeso que enriquecieron las paredes y arcos de la capilla. De los artífices mencionados, se conocen noticias de dos de ellos. A Juan Francisco Hidalgo se le debe el cuerpo de la iglesia parroquial de Nuestra Señora de la Asunción de Santaella, realizado entre 1669 y 1685. Por su parte, Andrés Gutiérrez es el autor de la única portada existente en la iglesia conventual de San José de Córdoba, vulgo San Cayetano, obra realizada en 1638 siguiendo el diseño habitual de las portadas carmelitanas ${ }^{5}$. También recoge la documentación trabajos de carpintería, caso del "torneado de los balaustres para la puerta de la capilla", que costó 28 reales. Este dato informa que el recinto estuvo cerrado por una reja de madera abalaustrada, tal y como señalaba Ramírez de Arellano. Asimismo, consta en las cuentas la realización de "archivos, escaparate cajones y puertas" por Diego de Valencia a cambio de 8 reales por cada uno de los 98 días que estuvo trabajando, resultando un total de $784^{6}$. Finalmente, también se conoce el coste del retablo de la capilla, obra realizada en madera por el fraile dominico Juan Bautista, que recibió 2.000 reales y pudo quedarse con las maderas sobrantes de dicho trabajo.

No obstante, no cabe duda de que la obra más interesante de la primera capilla sacramental fue el lienzo de la Última Cena que la presidió (Figura 1), encargado al célebre pintor José Ruiz de Sarabia por 400 reales, y que con la construcción de la nueva capilla pasaría al retablo actual ${ }^{7}$. A pesar de la importancia de este artista, sevillano de nacimiento e hijo del también pintor Andrés Ruiz de Sarabia, su vida artística sigue necesitando nuevos estudios, por lo que la documentación de esta obra supone un paso adelante en la puesta en valor de este maestro pintor, cuyos trabajos coincidieron con los de Antonio del Castillo y Valdés Leal en la Córdoba del siglo XVII ${ }^{8}$. Dicha pintura se enriqueció con un marco que se encargó a un autor desconocido de fuera de la ciudad. Conservado en el retablo actual, está tallado con gallones en el canto, perteneciendo a una tipología

${ }^{5}$ Villar Movellán/Dabrio González/Raya Raya, 2005: 414.

${ }^{6}$ Junto a dicho carpintero trabajó un oficial que recibió 7 reales cada día de los 87 que colaboró, ganando un total de 609 reales.

7 Nieto, 2019.

${ }^{8}$ Sobre José Ruiz de Sarabia, véase Valverde Madrid, 1963. Pérez Sánchez, 1986: 272. Palomino de Castro y Velasco, 1988: 300-302. Ceán Bermúdez, 2001: 354. 
muy representativa de la España de finales del siglo XVI y que se desarrolló hasta avanzado el siglo XVII ${ }^{9}$.

Poco se conocía acerca de la actual capilla sacramental de la parroquia de San Miguel. En 1970, Serrano Ovín sacó a la luz un extracto del acta capitular de 20 de octubre de 1760 en el que se recogía la petición de la cofradía del Santísimo Sacramento para ensanchar la nueva capilla, cuando era hermano mayor don Manuel Vaquerizo. Por su parte, el ayuntamiento acordó que los capitulares don Martín de Fuiral y don Fernando Muñoz comprobaran, junto al maestro mayor y alarife, el lugar donde la corporación pretendía llevar a cabo la obra, para conceder la licencia en el caso de no existir perjuicio alguno ${ }^{10}$. En las cuentas de la cofradía correspondientes a esa época, se afirma que la capilla anterior resultaba pequeña e incómoda para los fieles que recibían la comunión, sobre todo los días de cumplimiento del precepto anual. Por ello, el obispo don Miguel Vicente Cebrián dispuso su traslado a la capilla de San Antonio, situada en el ábside izquierdo del templo, construyéndola nueva y de mayor amplitud, para lo que sería necesaria la petición de la mencionada licencia al concejo ${ }^{11}$.

Desde el punto de vista arquitectónico, la nueva capilla (Figura 2) ha sido relacionada con la contemporánea de la parroquia de la Asunción de La Rambla, que también corresponde a una remodelación de otra capilla anterior ${ }^{12}$. La capilla de San Miguel es de planta rectangular y está dividida en tres tramos, uno central cuadrado y dos rectangulares en los extremos. El espacio cuadrangular está cubierto por una bóveda de media naranja, mientras que los tramos rectangulares están cerrados con bóvedas de medio cañón ${ }^{13}$. A raíz de esta obra, la capilla perdió su altura original, ocultando su arquitectura gótica y lográndose una concepción espacial más acorde con su tiempo, lo que provocó las críticas de Ramírez de Arellano en sus Paseos, imbuido por el romanticismo de la época ${ }^{14}$.

Según consta en una relación diaria de los gastos, las obras de la capilla estuvieron a cargo de los maestros Antonio de Morales y Francisco de la Cruz, invirtiendo la cofradía en cantería la suma de 18.361 reales y 23 maravedís. Los gastos se recogen en un pequeño cuaderno adjunto a las cuentas, donde se especifica por meses el dinero empleado en las obras. De esta forma, los primeros gastos que aparecen señalados corresponden a los tres pliegos de papel necesarios para los trámites administrativos con la ciudad, es decir, para los autos, licencia y testimonio que permitieran ampliar la capilla. Asimismo, aparecen las cantidades

9 Timón Tiemblo, 2002: 207-210.

${ }^{10}$ Serrano Ovín, 1970: 75-76.

11 AGOC, sección Cofradías, Cuentas de la cofradía del Santísimo Sacramento de la parroquia de San Miguel, 1774.

12 Rivas Carmona, 1982: 306.

13 Villar Movellán/Dabrio González/Raya Raya, 2005: 142-143.

${ }^{14}$ Ramírez de Arellano, 2003: 8. 
destinadas a agasajar al oficial de la escribanía, al maestro mayor y a los alarifes, así como los del chocolate que se dio a los diputados y al escribano de la ciudad. Tras estos gastos, a partir del mes de octubre de 1760 aparecen señalados los relativos a la obra propiamente dicha, recogiendo los pagos a los dos oficiales de albañilería, a los peones, al tallista por apear el retablo, al cantero o al aprendiz de carpintería. También se indican los correspondientes a portes por cargas de piedra, de arena o de granzas, a los del aserramiento de tablones, o incluso los habidos por la composición de una escalera prestada que se rompió. Del mismo modo, se recogen las compras de materiales como sogas, clavos, cintas, espuertas, berlingas, ladrillos para las bóvedas, cántaros y macetillas, de palos de pino procedentes de la sierra, de fanegas de yeso, de tablas, de banquillos gruesos de álamo, del cerrojo y la llave del postigo, de cargas de cascos para los tejados, de cahíces de cal, de hierro para el florón de la capilla, o de incluso una cerraja para la puerta de la sacristía de la nueva capilla ${ }^{15}$.

No obstante, además de estos sencillos e inespecíficos apuntes, aparecen otros más interesantes, como los correspondientes a la realización de dos rejas para las ventanas del testero de la capilla, encargadas en enero de 1761 y que costaron 49 reales y 30 maravedís. Gracias a esta información, se corrobora que en su origen el retablo no contaba con pinturas laterales en su segundo cuerpo, sino que permitía ver los dos vanos abiertos en el muro y que hoy aparecen tapiados por el exterior, enmarcando una lápida con un cáliz fechada en 1761 que probablemente sea el que se realizó durante el mismo mes de enero por una cantidad de 6 reales. En agosto de 1761 aparece referido el gasto de realización de un bastidor de hierro para una rejilla de alambre de la ventana grande, la cual hoy conecta con la planta superior de la sacristía. También se recoge la compra de 24 vidrios procedentes de Sevilla para las tres ventanas de la capilla y la de un cuartillo. Por tanto, la capilla contaba con tres ventanas que hoy no tienen funcionalidad, al estar las dos del testero tapiadas y la grande conectando con la sacristía. Otro dato interesante corresponde a marzo del mismo año, cuando se entregaron 150 reales al peón Francisco Rodríguez por las más de un centenar de noches que pasó en la iglesia, vigilándola mientras que la pared de la capilla estaba derribada y era reconstruida. Por otra parte, en agosto se pagó el empedrado de los alrededores de la capilla, y también de la muy cercana ermita de San Zoilo, donde según se refleja en dicha relación, estuvo el Santísimo durante las obras. En noviembre, una vez retirados todos los andamios, la calle trasera de la parroquia sería empedrada por segunda vez ${ }^{16}$.

${ }^{15}$ AGOC, sección Cofradías, Cuentas de la cofradía del Santísimo Sacramento de la parroquia de San Miguel, 1774.

${ }^{16}$ AGOC, sección Cofradías, Cuentas de la cofradía del Santísimo Sacramento de la parroquia de San Miguel, 1774. 
La construcción de la capilla queda recogida en las dos lápidas con marcos de yeso que se encuentran a su entrada, donde se puede leer en latín: "Siendo Sumo Pontífice Clemente XIII, Rey de España Carlos III, Obispo de Córdoba Martín de Barcia, Rector de esta iglesia de San Miguel Juan de Segovia y Hermano Mayor de la cofradía del Santísimo Sacramento Manuel de Baquerizo, con el auxilio de Dios y ayuda del Prelado, fue de nuevo construida esta capilla de San Antonio (a la mayor Gloria de Dios) por la cofradía en el año 1761 de la Natividad del Señor".

Pasando al proceso ornamental, el mismo cuaderno adjunto a las cuentas de la cofradía incluye en una segunda parte la relación de gastos por la realización del retablo y de la talla en yeso de la capilla. La historiografía ha considerado que el retablo barroco del sagrario de San Miguel fue realizado por Teodosio Sánchez Cañada en la década de 1760, señalándose que es una obra muy plana en la que los elementos constructivos carecen de fuerza arquitectónica (Figura 3). Destacan las columnas salomónicas del primer cuerpo, que conviven con unos estípites muy sencillos en el remate. Se ha considerado que el protagonismo compartido entre la pintura y la escultura da como resultado una obra bastante arcaica para la época en la que se construye, si bien esta información ignora que el retablo no contaba en su origen con las dos pinturas laterales ${ }^{17}$. Compuesto de banco, dos cuerpos y tres calles, parece evidente que fue realizado expresamente para acoger el lienzo de la Última Cena realizado por Ruiz de Sarabia para la capilla primitiva. Por esta razón, la calle central es bastante más ancha, acogiendo dicha pintura con su marco original. En el primer cuerpo, destacan las hornacinas de las calles laterales, con las imágenes de San Joaquín y Santa Ana. Las columnas salomónicas enmarcan la calle central, donde además del lienzo de la Santa Cena aparecen, sobre unas repisas y flanqueando el tabernáculo, las esculturas de San José y de la Inmaculada Concepción. En el remate, a ambos lados se pueden contemplar dos lienzos de la Oración en el Huerto y del Prendimiento de Jesús, mientras que en la calle central se sitúa la imagen escultórica de San Antonio, titular de la capilla, y las de San Gabriel y el Santo Ángel de la Guarda, rematando todo el conjunto un lienzo de la Piedad ${ }^{18}$. Respecto a los motivos decorativos del retablo, se comprueba cómo comienza a aparecer la rocalla, que se venía manifestando en Córdoba desde $1755^{19}$ y que también constituye la ornamentación de las yeserías de esta capilla.

Mediante la consulta de la citada relación de gastos, se puede descartar que Teodosio Sánchez Cañada fuera el autor del retablo, ya que realmente fue encargado a un artista hasta hoy desconocido, Simón de León. Junto a su hermano y otros oficiales, realizaría también el resto de las obras en madera, como las

\footnotetext{
17 Valverde Madrid, 1974: 242. Raya Raya, 1980: 122-124.

18 Villar Movellán/Dabrio González/Raya Raya, 2005: 142-143.

19 Raya Raya, 1980: 86.
} 
puertas, bancas y mesas, al igual que también fue el encargado de la talla de las yeserías con sus escudos, dando comienzo todas estas labores el 9 de febrero de 1761, año que aparece inscrito en el arco de ingreso de la capilla ${ }^{20}$. El costo total del trabajo de Simón de León fue de 9.166 reales, incluyendo el retablo, las yeserías y el resto de trabajos en madera. Del mismo modo que se hizo para la ampliación de la capilla, la hermandad recogió detallada y cuidadosamente todos y cada uno de los gastos referentes a esta labor de talla. De esta forma, se indica el coste de libras de cola, de clavos, portes... y, sobre todo, los jornales del maestro, de los oficiales y de los aprendices. Llama la atención la referencia al sagrario propiamente dicho, para el que se compraron seis espejos procedentes de Sevilla. Asimismo, se pagaron 2 reales y 17 maravedís por los carretes para sus cortinas, pero también para las ventanas de la capilla, por 4 bisagras, tornillos, una cerraja, un pasador y otras piezas metálicas para la puerta del sagrario y las cortinas. El coste fue de 52 reales. También se señalan unos gastos relativos a la arquita con la llave del sagrario, destinando la cofradía un total de 56 reales para dicho objeto dorado a fuego y con un cordón de oro realizado por Pedro de Luna ${ }^{21}$. Sin embargo, el sagrario original no se conserva, desconociéndose la procedencia del actual, también de estética setecentista.

Respecto a las yeserías, como en prácticamente toda la arquitectura andaluza de los siglos XVII y XVIII, caracterizada por su tradicionalismo tipológico y por su simplicidad tectónica, son elementos sustanciales que rompen la monotonía de este espacio sacramental. La ornamentación de yeserías permite tanto destacar las formas arquitectónicas como ocultarlas, logrando un espacio "cueviforme", donde el empleo del color y el dorado contribuye a alterar la relación entre apariencia y realidad, siendo reforzado todo ello con los contrastes entre oscuridad y claridad y por la gradación entre ambas ${ }^{22}$. Guardando las distancias con otras capillas de mayor riqueza ornamental, así ocurre en la capilla sacramental de la parroquia de San Miguel, cuyo simple esquema arquitectónico queda resaltado con estos ornamentos. Las llamadas "yeserías fingidas" también hacen acto de presencia en este espacio sacramental, junto a las ornamentales letras que inscriben en los muros mensajes relativos a la Eucaristía. Teniendo en cuenta que en el siglo XVIII no existía la iluminación eléctrica que hoy se emplea en la capilla, la original procedería de las mencionadas vidrieras o de las velas, por lo que sería complicado para el espectador distinguir entre las yeserías reales y las fingidas, sobre todo en el primer golpe de vista ${ }^{23}$.

${ }^{20}$ AGOC, sección Cofradías, Cuentas de la cofradía del Santísimo Sacramento de la parroquia de San Miguel, 9-2-1761.

${ }^{21}$ AGOC, sección Cofradías, Cuentas de la cofradía del Santísimo Sacramento de la parroquia de San Miguel, 26-9-1762.

${ }_{22}$ Morales, 2015: 168.

${ }_{23}$ Morales, 2009: 148-149. 
Como bien es sabido, la decoración en yeso es uno de los ingredientes más característicos de la arquitectura dieciochesca en Córdoba, confiriéndole su carácter más distintivo ${ }^{24}$. A mediados del siglo XVIII hicieron su aparición los motivos de rocalla, que son precisamente los que ornamentan el espacio sacramental de San Miguel, contrastando sobre el fondo blanco por su policromía dorada y azul (Figura 4). El primer lugar donde se manifiestan estos motivos es en la portada de la propia capilla, cuyo arco de medio punto se encuentra rematado por una orla sinuosa de yeserías con flores y rocallas que rodean la representación del cáliz con la Sagrada Forma. Todo ello está inscrito en una moldura polilobulada bajo la que se lee pintado en dorado el texto "O SACRVM CONVIVIVM IN QVO CHRISTVS SVMITVR", atribuido a Santo Tomás de Aquino en honor al sacramento de la Eucaristía. Además, se advierten motivos vegetales pintados y la inscripción con la fecha de construcción de la capilla "AÑO D 1761". Una vez en el interior, se puede comprobar cómo las dos bóvedas de cañón de los extremos presentan unos nervios de yeserías de motivos vegetales. A la vez, los arcos fajones aparecen decorados con los textos "LAVDATE DOMINIVM OMNES GENTES" (Salmo 117) y "O ALTITVDO DIVITIARVM SAPIENTIAE ET SCIENTIAE DEI” (Romanos 11, 33). En la sección inmediata al retablo se encuentra además otra inscripción pintada entre los nervios de yeso, correspondiente al himno eucarístico escrito por Santo Tomás de Aquino para la festividad del Corpus Christi "PANGE LINCVA GLORIOSI CORPORIS MISTERIVM". Estas letras aparecen rodeadas por yeserías fingidas, abigarrando así la bóveda más próxima al tabernáculo, como corresponde al espacio preferente de la capilla. Respecto a la media naranja, también presenta combinación entre yeserías reales y fingidas. En las pechinas destacan los relieves veterotestamentarios de los panes de la proposición y el transporte del racimo de uvas de Caleb, y los del Pelícano y el Cordero Místico sobre el Libro de los Siete Sellos portando el lábaro sagrado, todos ellos rodeados por dorados motivos de rocalla ${ }^{25}$. La bóveda está dividida por ocho nervios en cuyos arranques destacan unas ménsulas decoradas con yeserías vegetales, mientras que en la clave aparece un florón, también ornamentado con yesos dorados y policromados en azul. El resto de la decoración responde a las yeserías fingidas, acompañadas de cartelas con una inscripción de letras doradas, esta vez en castellano: "Alabado sea el Santísimo Sacramento del altar y María Santísima Concebida sin pecado original”.

Las cuentas revelan el nombre del maestro dorador y pintor encargado del dorado y policromía del retablo y de la ornamentación de la bóveda, Luis José Gómez, conocido solamente por haber retocado en 1771 la imagen de la actual Virgen de Gracia y Amparo, titular de la hermandad de la Sentencia, y por el

\footnotetext{
${ }^{24}$ Rivas Carmona, 1982: 66.

${ }^{25}$ Sobre estas representaciones eucarísticas, véase González Torres, 2016: 311-383; 2009.
} 
dorado del retablo mayor de la iglesia conventual de San José y Santa Teresa de Bujalance, labor realizada en 1776 junto al también dorador Francisco de Burgos $^{26}$. El 18 de mayo de 1762 firma un recibo por 11.296 reales y 8 maravedís por las citadas labores en la capilla, especificando dicho documento que el artífice dio buena limosna al Santísimo, incluyéndose una gratificación a los oficiales para que concluyeran la obra con más celeridad de lo previsto. Este documento hizo que fueran destruidos todos los papeles y recibos existentes antes de este ajuste. Al día siguiente se firmó otro recibo, donde el maestro dorador recibió 2.464 reales y 24 maravedís por labores ornamentales fuera del retablo, es decir, por las yeserías fingidas y las letras ${ }^{27}$. Evidentemente, la ornamentación que se observa actualmente en la capilla no es la original, ya que a lo largo de los siglos ha sufrido intervenciones y restauraciones que han desvirtuado su aspecto primigenio. Por ejemplo, las cuentas de la cofradía correspondientes al período comprendido entre 1793 y 1798 hacen referencia a unas obras de restauración en las bóvedas, que se habían "descortezado" y desconchado, lo que obligó a acometer una renovación completa de las yeserías. El encargado de estas obras, llevadas a cabo en 1796, fue el maestro albañil Antonio José de Salas, de quien no se conocen otras noticias. Por otra parte, es evidente que la decoración de yesos ha debido sufrir intervenciones mucho más recientes.

Según indican las cuentas, la labor escultórica de la capilla fue encargada, originalmente, a dos escultores. En primer lugar, destaca la figura del insigne Alonso Gómez de Sandoval, del que se conocen numerosas obras y que se caracterizó por dotar a sus imágenes de un carácter más delicado, reposado y elegante, fruto de sus titubeos entre lo barroco y lo neoclásico ${ }^{28}$. El 8 de mayo de 1762, el escultor firmó un recibo de 1.300 reales de vellón por la realización de cuatro imágenes para la capilla sacramental y su retablo, concretamente las de San Miguel, San Rafael, San Joaquín y Santa Ana ${ }^{29}$. Las pequeñas imágenes de San Joaquín y Santa Ana (Figura 5) son las únicas que se mantienen en el retablo, mostrando una calidad acorde con su autor y una gran diferencia técnica respecto al resto de esculturas. Respecto a las tallas de los arcángeles, hoy día no se encuentran en la capilla, pudiendo tratarse de los que actualmente ocupan las dos hornacinas del segundo cuerpo del retablo mayor de la parroquia, muy próximas a la estética de Gómez de Sandoval, aunque de mayor tamaño que las comentadas. Sin embargo, el hecho de que en el recibo se especifique que el encargo se hace "para la capilla

${ }^{26}$ Villar Movellán/Dabrio González/Raya Raya, 2006: 113 y 321.

27 AGOC, sección Cofradías, Cuentas de la cofradía del Santísimo Sacramento de la parroquia de San Miguel, 18-5-1762.

28 Villar Movellán sitúa a este escultor en una segunda etapa dentro de la escultura barroca cordobesa. Villar Movellán, 1984: 377.

29 AGOC, sección Cofradías, Cuentas de la cofradía del Santísimo Sacramento de la parroquia de San Miguel, 8-5-1762. 
y retablo", puede llevar a pensar que estas imágenes pudieron haber estado en algún lugar de la capilla diferente al altar.

Las restantes imágenes del retablo, a excepción de San Antonio, cuyo autor es desconocido, fueron encargadas a otro artista. En un recibo firmado el 5 de octubre de 1762 se revela que fue el escultor Clemente de Lara quien talló las imágenes de la Inmaculada, San José, San Gabriel y del Santo Ángel de la Guarda, por la cantidad de 690 reales $^{30}$. Dicho autor solo es conocido por la realización en 1747 de la imagen pétrea y policromada de Nuestra Señora del Socorro, situada en la hornacina de la portada de la ermita de dicha advocación ${ }^{31}$. De hecho, en el recibo se describe al autor como "artífice de escultura y de talla", y se señala que realiza estas pequeñas imágenes en madera y estofadas expresamente para el retablo de la nueva capilla, habiendo entregado además "buena limosna en ellas" 32 . La calidad artística de estas tallas dista mucho de la demostrada por Alonso Gómez de Sandoval en las de Santa Ana y San Joaquín, mostrándose más hieráticas, menos naturalistas y con poca expresividad.

Finalmente, la cofradía encargó una serie de lienzos para decorar la capilla, conservándose en su lugar la inmensa mayoría. Las cuentas revelan una serie de encargos al pintor Pedro Ruiz Moreno, quien según el recibo firmado el 28 de septiembre de 1762 cobró un total de 2.265 reales de vellón. Sin embargo, el pintor no sólo se limitaría a la realización de obras de nueva factura, ya que también le fue encargada la restauración del lienzo de la Última Cena de José de Sarabia por 50 reales y el retoque de dos lienzos de San Juan y María Magdalena, que fueron donados en su tiempo por un cofrade llamado don Pedro de Fuentes ${ }^{33}$. Respecto al mencionado autor, a través de la comparación de estos lienzos con otras obras conservadas, cabe considerar que se trata de Pedro Ruiz Morián Moreno, también conocido por Pedro Moreno. De este artista se conoce muy poco, aunque trabajó en la catedral cordobesa, realizando las pinturas laterales del retablo de la capilla de San Ambrosio en 1723, correspondientes a la Ascensión del Señor y a la Adoración de los Reyes. También para la catedral realizó el valioso cuadro de la Anunciación del retablo de la capilla de la Encarnación (1743), al igual que el magnífico retablo salomónico en trampantojo ubicado en la capilla del Bautismo, pintado en $1723^{34}$. En la sala IV del Museo Diocesano también se

${ }^{30}$ AGOC, sección Cofradías, Cuentas de la cofradía del Santísimo Sacramento de la parroquia de San Miguel, 5-10-1762.

31 Villar Movellán/Dabrio González/Raya Raya, 2006: 177.

32 AGOC, sección Cofradías, Cuentas de la cofradía del Santísimo Sacramento de la parroquia de San Miguel, 5-10-1762.

${ }^{33}$ Los datos que siguen proceden del mismo documento. AGOC, sección Cofradías, Cuentas de la cofradía del Santísimo Sacramento de la parroquia de San Miguel, 28-91762.

${ }^{34}$ Nieto Cumplido, 1998: 345, 408 y 412. 
conservan algunas obras de este pintor ${ }^{35}$. Sin embargo, las pinturas de la capilla sacramental de la parroquia de San Miguel fueron realizadas en fechas posteriores a las indicadas, por lo que, en caso de ser de este autor, corresponderían a los últimos años de su vida.

Ramírez de Arellano consideró estos lienzos de más o menos mérito ${ }^{36}$. Llaman especialmente la atención los dos de mayor tamaño, que representan según el recibo a "dos evangelistas y un Príncipe de los Apóstoles", y que costaron ambos 500 reales. En el muro izquierdo se encuentra el correspondiente a San Lucas y San Marcos, quienes custodian a San Pablo, alzándose los tres personajes sobre unas peanas y portando sus atributos (Figura 6). Asimismo, los dos evangelistas se representan escribiendo con una pluma sobre pergaminos donde se leen en latín pasajes de sus evangelios relativos a la institución de la Eucaristía (Lucas 24, 30 y Marcos 14, 22). Lo mismo ocurre con el libro que porta San Pablo en su mano izquierda, con versículos de la Primera Epístola a los Corintios (I Cor 11, 23-27), mientras que con la derecha sujeta la espada. El mismo esquema sigue el lienzo frontero, donde San Pedro, San Mateo y San Juan aparecen de nuevo con sus atributos y portando versículos relacionados con la institución de la Eucaristía (Juan 6, 59; Mateo 22, 12; y II Pedro 1, 4).

Otras pinturas presentan temas de la Pasión de Cristo, que en las capillas sacramentales puede ser entendida como el camino a seguir para alcanzar la gloria, según indica Moreno Cuadro en su estudio del tabernáculo del sagrario catedralicio. Dicho camino ya lo siguieron los mártires, cuyo sacrificio entronca con el martirio de Jesús en la tierra para redimir a la humanidad ${ }^{37}$. Estas pinturas pasionistas, que costaron 200 reales, representan la escena de la Oración en el Huerto y de Nuestra Señora de los Dolores, haciendo referencia al momento en que Cristo acepta su sacrificio ante Dios y al dolor de María al pie de la cruz por la pasión y muerte de su Hijo. No dejan de pertenecer a la temática de la Pasión las pinturas de María Magdalena y San Juan Evangelista, de autor desconocido, de clara tendencia claroscurista y de marcado carácter naturalista. Retocados por Pedro Ruiz Moreno en el mismo año de 1762 por 40 reales, fueron concebidos por la cofradía junto a los dos anteriores, apareciendo dispuestos al mismo nivel y en parejas.

Las pinturas de la Aparición de San Rafael al padre Roelas y de los Santos Mártires, Acisclo y Victoria se encuentran enfrentadas justo al principio de la capilla. De menor tamaño que las anteriores, costaron 100 reales cada una. Respecto a la presencia de los Santos Mártires en las capillas sacramentales, es algo frecuente en Córdoba desde que César Arbasia los representase en la capilla del Sagrario de la catedral. Lo mismo ocurre con San Rafael Arcángel, custodio de la ciudad cuyas apariciones fueron paralelas al descubrimiento de las reliquias

\footnotetext{
${ }^{35}$ Villar Movellán/Dabrio González/Raya Raya, 2006: 77-78.

${ }^{36}$ Ramírez de Arellano, 2003: 8.

${ }^{37}$ Moreno Cuadro, 2018: 325-349.
} 
de los Santos Mártires en la parroquia de San Pedro. Una vez más, Pedro Ruiz Moreno acude a la introducción de textos en sus lienzos, de modo que en el de la Aparición de San Rafael al padre Roelas aparece el célebre Juramento ${ }^{38}$ que surge del arcángel. Por su parte, el clérigo aparece sentado tras un escritorio sobre el que descansan un libro, una vela y un pergamino que estaba escribiendo, acentuando así la sensación de sorpresa ante el acontecimiento. Por su parte, los Mártires aparecen con sus palmas y los elementos y marcas de su martirio, mientras que al fondo se puede observar un paisaje donde se alza la ciudad de Córdoba, de la que son patronos.

Las tres pinturas de Pedro Ruiz Moreno más cercanas al retablo de la capilla y, por consiguiente, al sagrario propiamente dicho, son las de La Encarnación y las referentes a los milagros de Jesús. La cercanía de estas temáticas a la presencia real de Cristo puede resultar evidente, ya que María es considerada el primer sagrario y los milagros acentúan el carácter sobrenatural del Salvador, subrayando así su divinidad. En el muro derecho, enfrentado a la ventana, se encuentra La Encarnación, realizada a la misma vez que los dos lienzos anteriores y por el mismo precio. En el lienzo aparecen María, San Gabriel y Dios Padre, y una vez más se acude a los textos en latín, mostrando el diálogo entre el ángel y la Virgen recogido en Lucas 1, 35. En lo que respecta a los dos milagros, son las pinturas más pequeñas de todo el encargo, costando 75 reales ambas. Correspondientes al Milagro del Energúmeno y al Milagro del Paralítico, en estos pequeños lienzos el pintor hace gala de su faceta como paisajista. De este modo, representa un paraje natural en el lienzo del endemoniado, cuya escena se desarrolla en la orilla del mar, destacando al fondo una ciudad sobre una montaña. Por el contrario, el momento de la curación del paralítico aparece en un escenario arquitectónico, demostrando el artista un buen dominio de la perspectiva y de la profundidad. En ambos lienzos aparece Jesucristo ante el enfermo, y tras él, sus apóstoles con rostros muy expresivos, impresionados ante el poder sobrenatural del maestro. Sin embargo, ambas pinturas se diferencian en el momento de la curación, ya que el endemoniado aún no está curado, mientras que el paralítico ya ha conseguido ponerse de pie y recoger su camilla. Todas las pinturas de las paredes se encuentran enmarcadas en yeso, siendo las de los evangelistas las más ornamentadas (Figuras 7 y 8 ).

El único lienzo que el pintor realizó para el remate del retablo representaba la Santísima Trinidad "con las tres partes iguales y distintas", recibiendo por el mismo 200 reales. Se desconoce al paradero de esta obra, retirada de su lugar en 1795 para ser sustituida por la actual Piedad, obra realizada por Francisco

${ }^{38}$ En el lienzo se lee el juramento que le hizo San Rafael al padre Andrés de las Roelas: "Yo te juro por Jesucristo Crucificado que soy Rafael, Ángel a quien Dios tiene puesto por Guardián de esta Ciudad". 
Agustín Grande por 220 reales de vellón ${ }^{39}$. Por otra parte, los dos vanos con los que contaría el segundo cuerpo del retablo debieron tapiarse en la primera mitad del siglo XIX, cuando el pintor Diego Monroy firma la realización de las pinturas que hoy ocupan esos huecos, correspondientes a otra Oración en el Huerto y al Prendimiento de Cristo $^{40}$.

En definitiva, la documentación de esta capilla constituye una sólida aportación al conocimiento del fenómeno sacramental en Córdoba, siendo una de las más interesantes desde el punto de vista ornamental, además de una buena prueba de la relevancia que alcanzaron las hermandades sacramentales en la ciudad durante el siglo XVIII. Asimismo, se amplía el catálogo de obras de autores tan relevantes como José Ruiz de Sarabia, Alonso Gómez de Sandoval o Francisco Agustín, así como también se amplia el conocimiento de otros menos conocidos y se sacan a la luz nuevos nombres sobre los que habrá que investigar, como por ejemplo Simón de León, el autor del retablo. Por ello, este artículo es un punto de partida para nuevas investigaciones que ayudarán a engrosar los estudios existentes sobre el barroco cordobés y sus artífices.

Fecha de recepción: 1 de octubre de 2019

Fecha de aceptación: 13 de abril de 2020

\section{BIBLIOGRAFÍA}

Aranda Doncel, Juan (2007): "Las cofradías del Santísimo Sacramento y la fiesta del Corpus durante los siglos XVI y XVII en Córdoba”. En: Linage Conde, Antonio (dir.): Minerva. Liturgia, fiesta y fraternidad en el Barroco español. Actas del I Congreso Nacional de Historia de las cofradías sacramentales. Sepúlveda: Cofradía del Corpus, pp. 273-296.

Ceán Bermúdez, Juan Agustín ([1800] 2001): Diccionario histórico de los más ilustres profesores de las Bellas Artes en España. Madrid: Akal.

González Torres, Javier (2009): Emblemata Eucharistica. Símbolos de la iconografía cristológica y sacramental. Málaga: Universidad de Málaga.

(2016): La capilla sacramental en el Barroco andaluz: espacio, simbolismo e iconografía (siglos XVI y XVIII). Tesis doctoral. Málaga: Universidad de Málaga. https://riuma.uma.es/xmlui/handle/10630/12832 (7-3-2020).

Morales, Alfredo J. (2009): "Yeserías fingidas en la Sevilla de finales del Seiscientos". En: Morales, Alfredo J. (coord.): Congreso Internacional Andalucía Barroca. Sevilla: Consejería de Cultura, Junta de Andalucía, vol. 1, pp. 147-158.

\footnotetext{
39 Archivo Parroquial de San Miguel (APSM), sección Cofradías, Cuentas de la cofradía del Santísimo Sacramento de la parroquia de San Miguel, 20-11-1795.

40 Ramírez de Arellano, 2003: 8.
} 
(2015): "Espacio y ornamento. El diseño de yeserías en la arquitectura sevillana del Barroco". En: De Cavi, Sabina (ed.): Dibujo y ornamento: trazas y dibujos de artes decorativas entre Portugal, España, Italia, Malta y Grecia. Estudios en honor a Fuensanta García de la Torre. Córdoba: Diputación Provincial de Córdoba, pp. 167-175.

Moreno Cuadro, Fernando (2018): "El tabernáculo de Guillermo Orta para la capilla del Sagrario en la catedral de Córdoba". En: Anuario de Historia de la Iglesia, 27, pp. 325-349.

Nieto, Miguel Á. (2019): "La Última Cena de la capilla sacramental de la parroquia cordobesa de San Miguel, nueva obra documentada del pintor sevillano José Ruiz de Sarabia (1656)”. En: Archivo Hispalense, 309-311, pp. 321-334.

Nieto Cumplido, Manuel (1991): "Cofradías y Hermandades: los laicos en la Reforma de la Iglesia (siglos XIV-XVI)”. En: Pozas Poveda, Lázaro (coord.): Córdoba: Tiempo de Pasión. Córdoba: Monte de Piedad y Caja de Ahorros de Córdoba, vol. 1, pp. 15-33.

(1998): La Catedral de Córdoba. Córdoba: Cajasur.

Palomino de Castro y Velasco, Antonio ([1715] 1988): El museo pictórico y Escala óptica. Madrid: Aguilar, vol. 3.

Pérez Sánchez, Alfonso E. (1986): Pintura barroca en España 1600-1750. Madrid: Cátedra.

Ramírez de Arellano, Teodomiro ([1875] 2003): Paseos por Córdoba, ó sean apuntes para su historia. Valladolid: Maxtor, vol. 3.

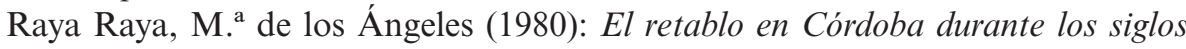
XVII y XVIII. Córdoba: Monte de Piedad y Caja de Ahorros de Córdoba.

Rivas Carmona, Jesús (1982): Arquitectura barroca cordobesa. Córdoba: Monte de Piedad y Caja de Ahorros de Córdoba.

Serrano Ovín, Vicente (1970): "La iglesia parroquial de San Miguel en Córdoba". En: Boletín de la Real Academia de Córdoba, de Ciencias, Bellas Letras y Nobles Artes, 90, pp. 71-98.

Timón Tiemblo, María Pía (2002): El marco en España del mundo romano al inicio del modernismo. Madrid: Publicaciones Europeas de Arte.

Valverde Madrid, José (1963): Dos pintores sevillanos en Córdoba: Sarabia y Valdés Leal. Sevilla: Imprenta Provincial.

(1974): Ensayo socio-histórico de retablistas cordobeses del siglo XVIII. Córdoba: Monte de Piedad y Caja de Ahorros de Córdoba.

Villar Movellán, Alberto (1984): "La imaginería cordobesa en el siglo XVIII". En: Peláez del Rosal, Manuel (dir.): El Barroco en Andalucía, Córdoba: Universidad de Córdoba/Diputación Provincial de Córdoba, vol. 1, pp. 373-386.

Villar Movellán, Alberto/Dabrio González, M. ${ }^{\mathrm{a}}$ Teresa/Raya Raya, M. ${ }^{\mathrm{a}}$ de los Ángeles (2005): Guía artística de Córdoba y su provincia. Córdoba: Fundación José Manuel Lara. 


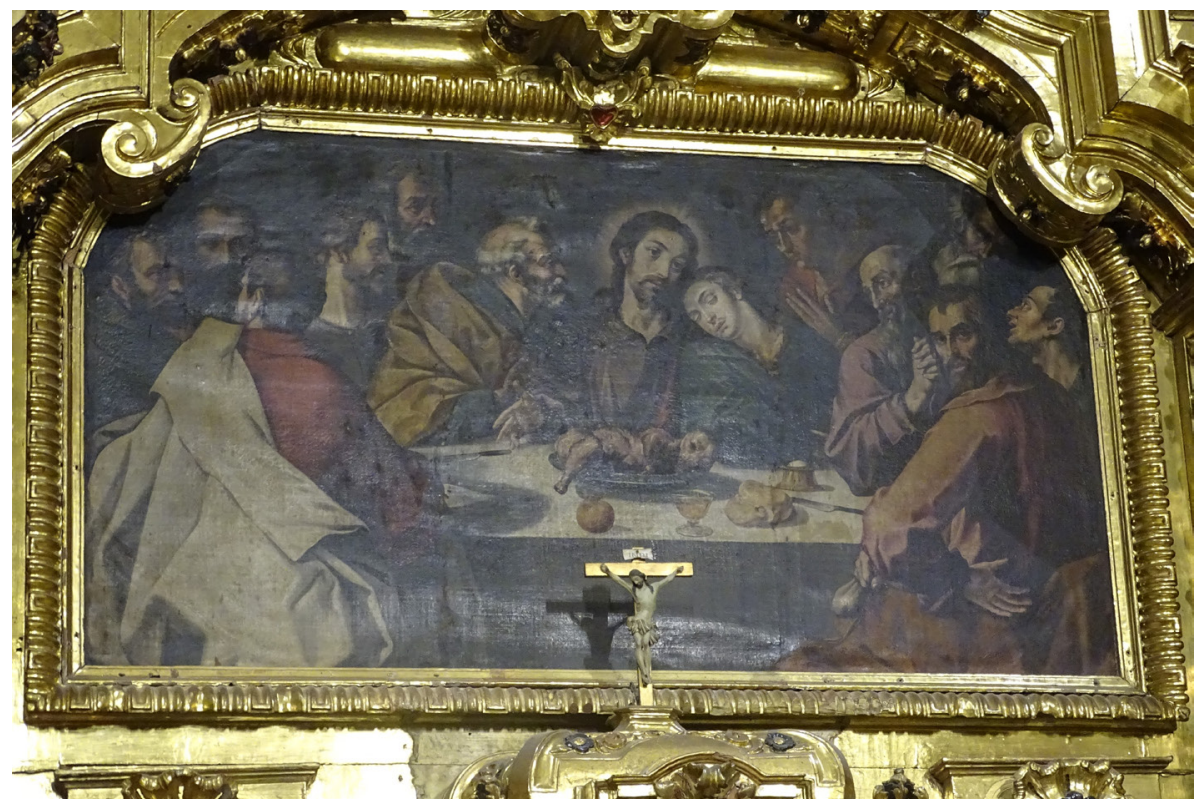

Figura 1. José Ruiz de Sarabia, La Última Cena, 1656, retablo de la capilla del Sagrario, parroquia de San Miguel, Córdoba. 


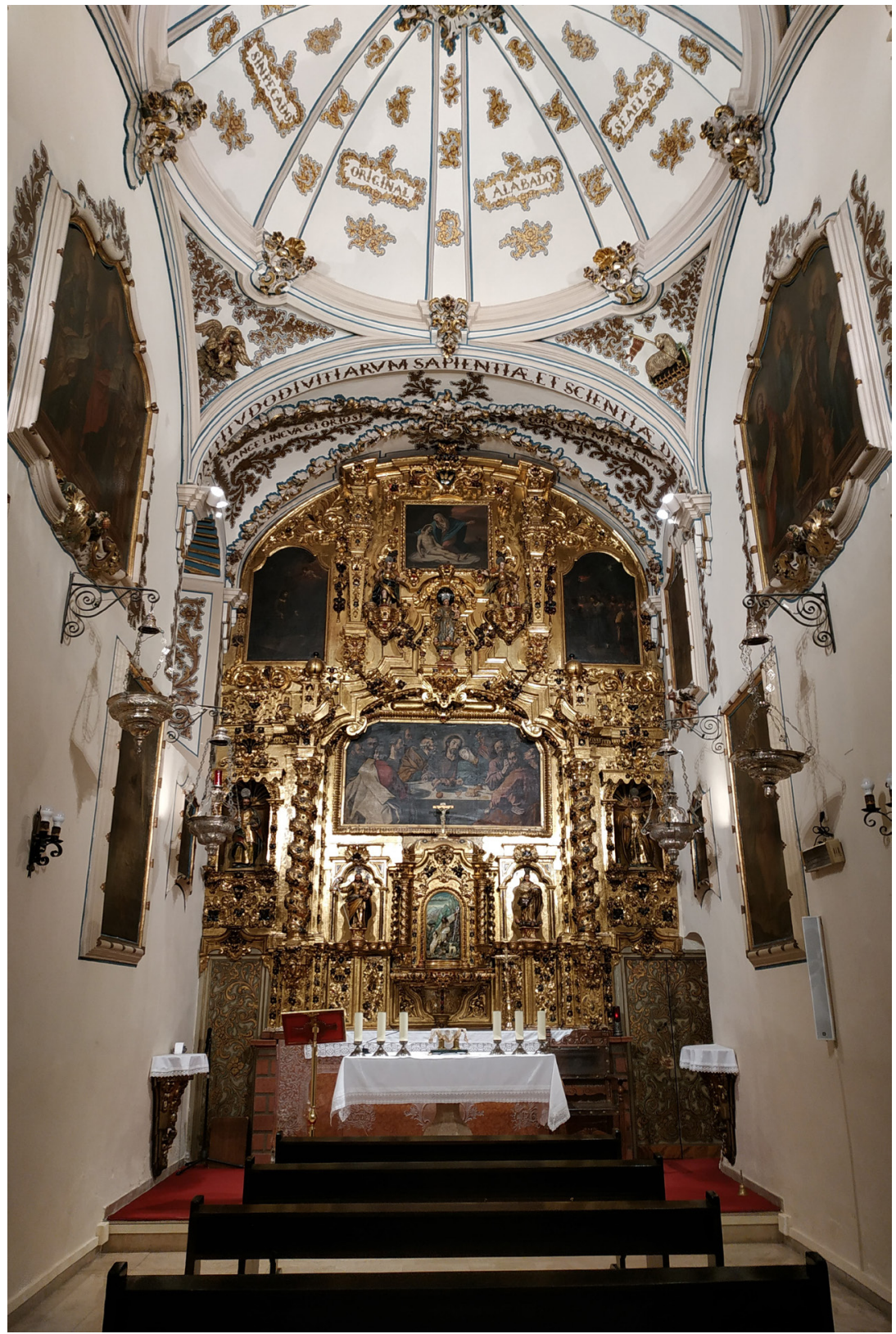

Figura 2. Antonio de Morales y Francisco de la Cruz, Capilla del Sagrario, 1761, parroquia de San Miguel, Córdoba. 


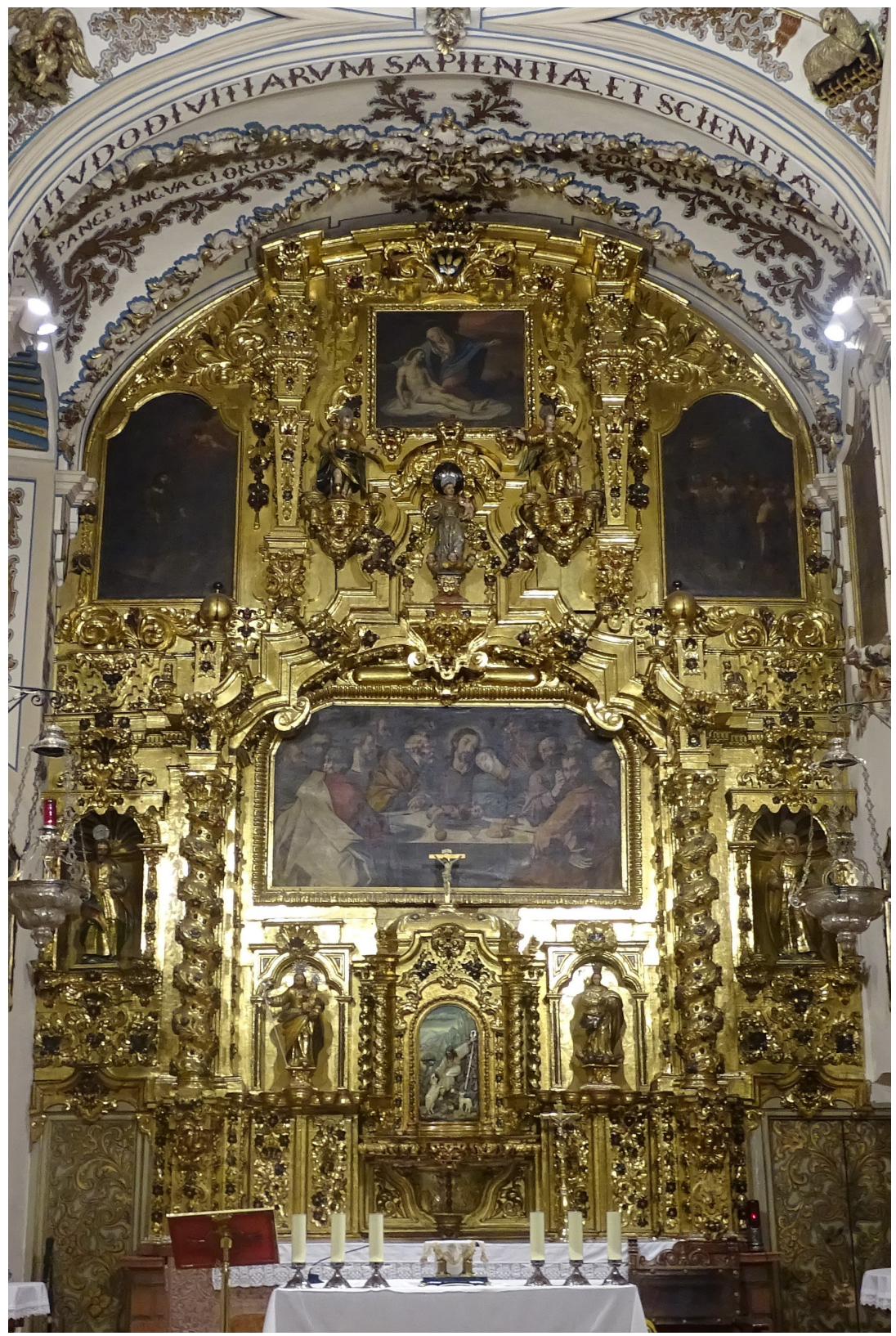

Figura 3. Simón de León, Retablo de la capilla del Sagrario, 1761, parroquia de San Miguel, Córdoba. 


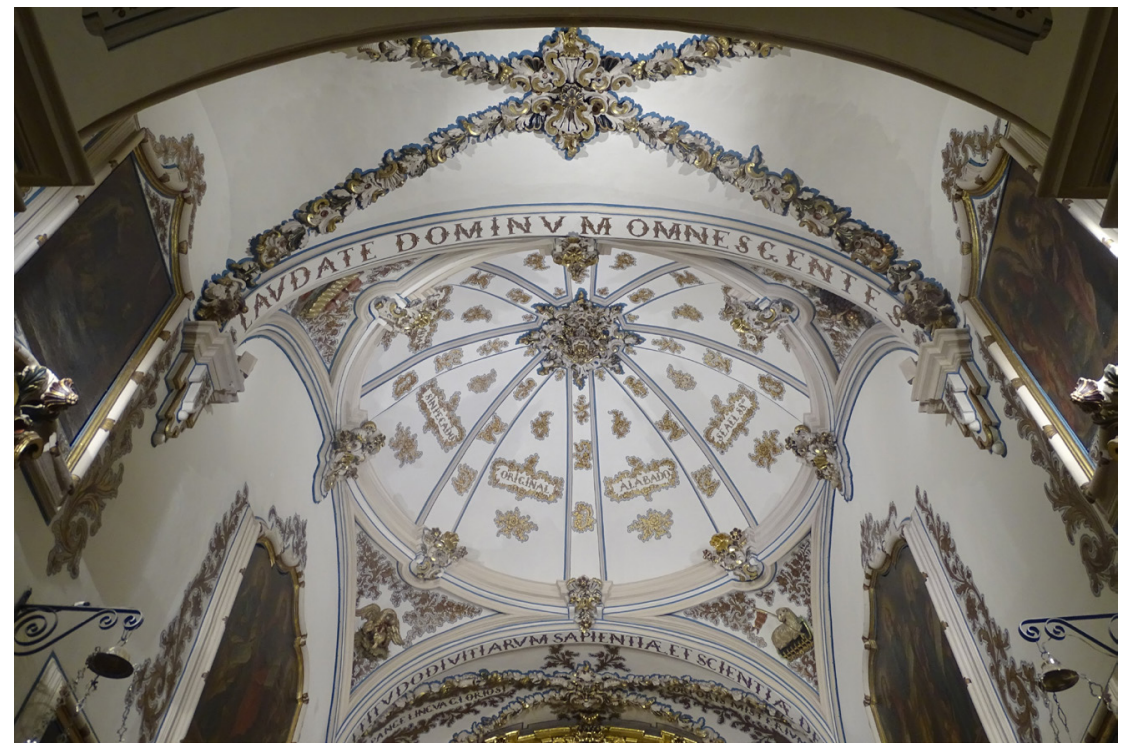

Figura 4. Anónimo, Yeserías de la capilla del Sagrario, 1761, parroquia de San Miguel, Córdoba.
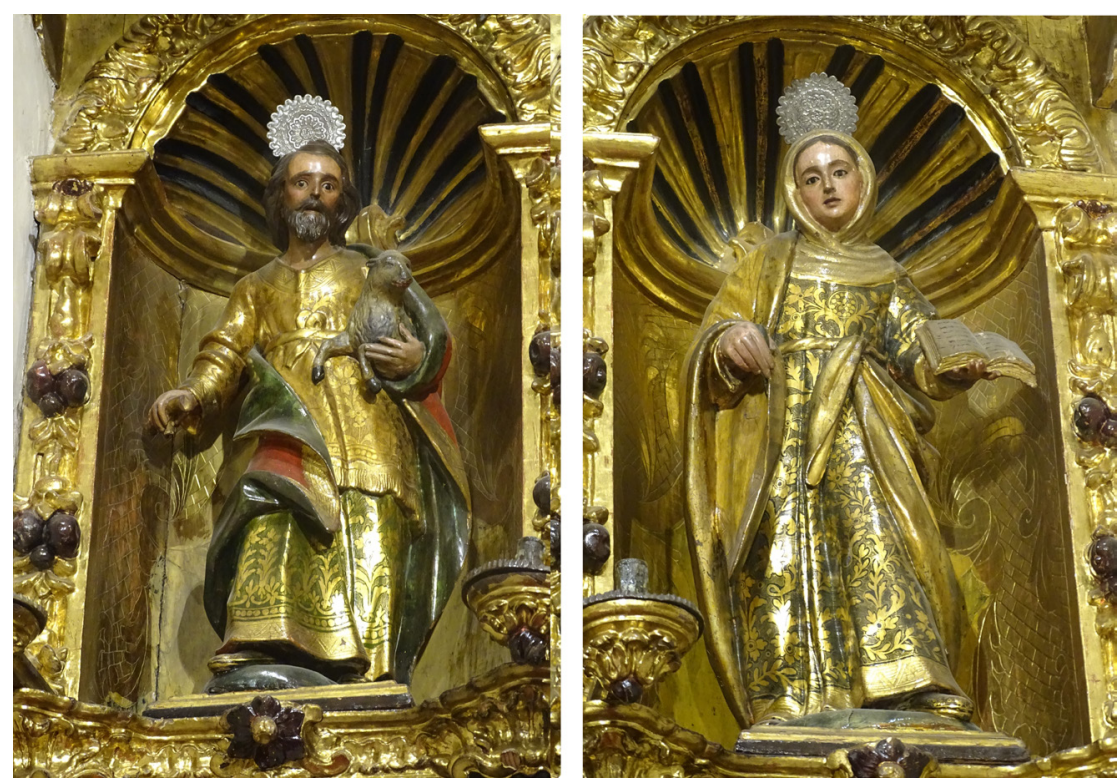

Figura 5. Alonso Gómez de Sandoval, San Joaquín y Santa Ana, 1762, retablo de la capilla del Sagrario, parroquia de San Miguel, Córdoba. 


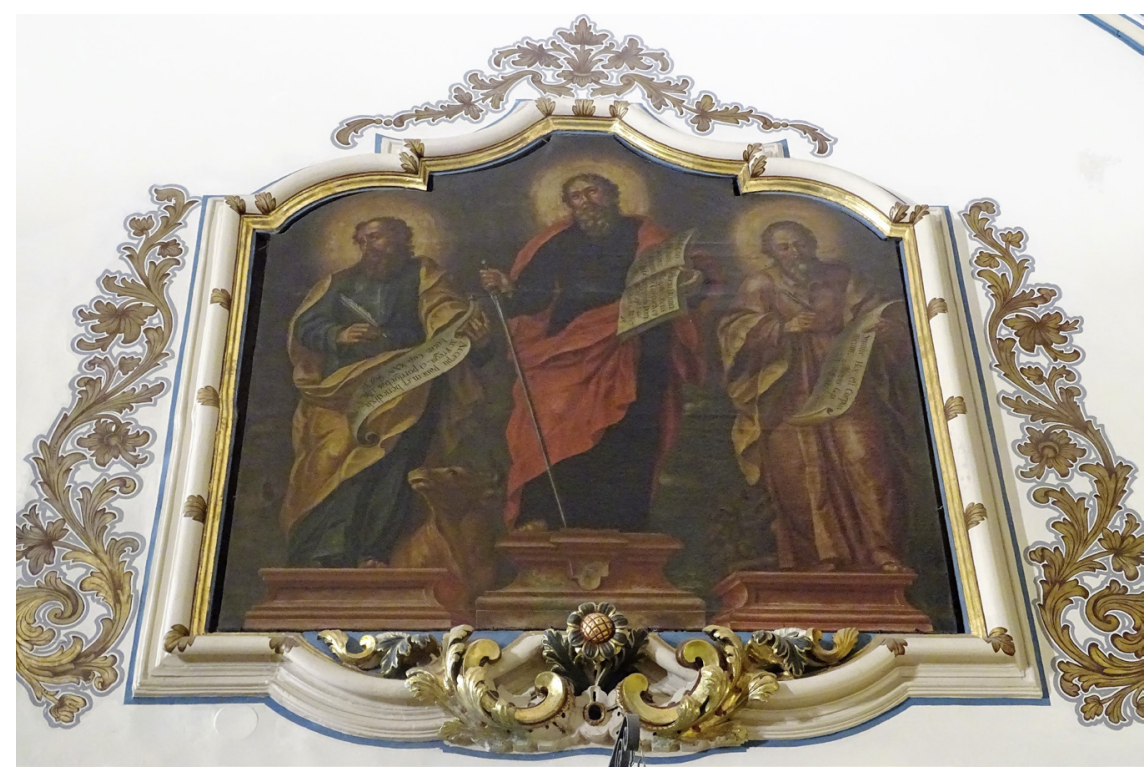

Figura 6. Pedro Ruiz Moreno, San Pablo acompañado de San Lucas y San Marcos, 1762, capilla del Sagrario, parroquia de San Miguel, Córdoba.

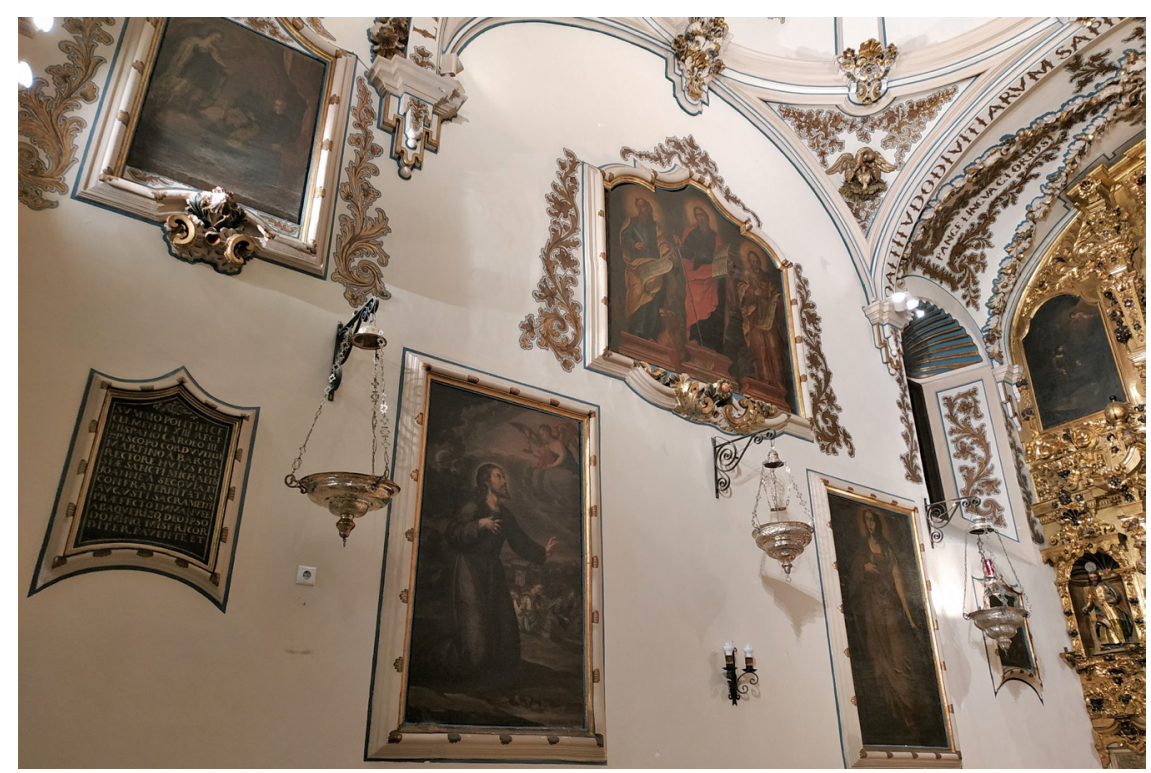

Figura 7. Pedro Ruiz Moreno, Pinturas de la capilla del Sagrario, 1762, parroquia de San Miguel, Córdoba. 


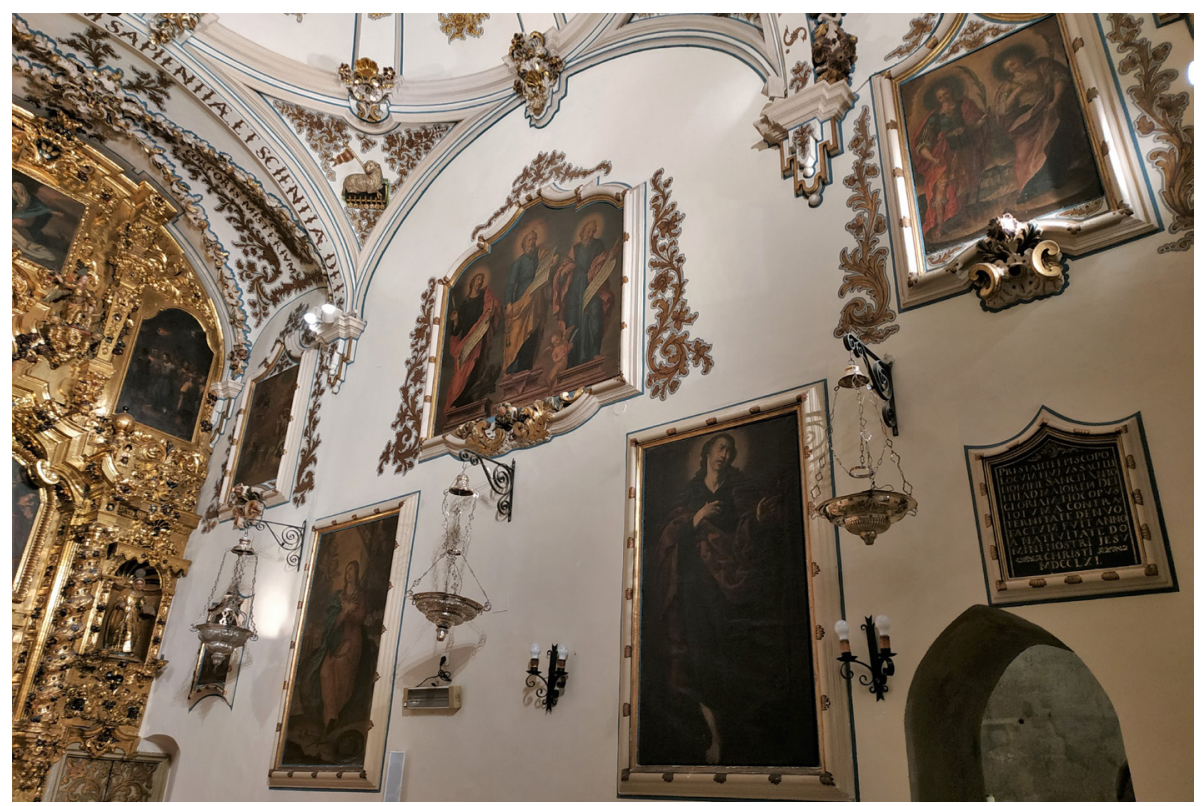

Figura 8. Pedro Ruiz Moreno, Pinturas de la capilla del Sagrario, 1762, parroquia de San Miguel, Córdoba. 